\title{
Dental Size and Morphology of Precontact Marshall Islanders (Micronesia) Compared with Other Pacific Islanders
}

\author{
Daris R. Swindler ${ }^{1}$ and Marshall I. Weisler ${ }^{2}$ \\ 1 Department of Anthropology, University of Washington, Seattle, USA \\ 2 Department of Anthropology, University of Otago, New Zealand
}

(Received November 2, 1999; Accepted May 12, 2000)

\begin{abstract}
The Marshall Island material is from five locations: the most southern Ebon Atoll; Kwajalein, Majuro, and Ujae atolls in the middle of the archipelago; and the southern Utrik Atoll. All but the Majuro skeletal and dental material was collected by MIW during archaeological excavations between 1993-1997. Crown dimensions and morphological observations were made of the teeth.

Shoveling was present on the upper incisors ranging from trace to semi-shovel in $92 \%$ of $\mathrm{I}^{1}$ 's and $90 \%$ of $\mathrm{I}^{2}$ 's. This was a somewhat higher percentage than for Yap upper incisors, although it was not significant and the degree of shoveling was similar (Harris and others, 1975). The hypercone of the upper molars was always present on $\mathrm{M}^{1-2}$ but was absent $17 \%$ on $\mathrm{M}^{3}$. Carabelli's trait had a low incidence in Oceania and cusps with free apices were rare. In precontact Marshallese, the cusps were present on $\mathrm{M}^{1} 39 \%$ which was about $10 \%$ higher than reported for Yap (Harris and others, 1975). There was a medium-sized cusp with an independent apex in $11 \%$ of $\mathrm{M}^{1}$ 's. Of six $\mathrm{dm}^{2}$ 's $33 \%$ had Carabelli's cusps. The $\mathrm{Y}$ occlusal groove pattern on $\mathrm{M}_{1}$ is fairly high in the Pacific (Swindler and others, 1998) and was present $90 \%$ of the time, the same figure reported for $M_{1}$ in Yap (Harris and others, 1975). The presence of cusp six varied from $3 \%$ to $70 \%$ on M1 in the Pacific. The latter figure was for Yap which was significantly higher than the $55 \%$ found in the Marshallese. $\mathrm{M}_{2}(21 \%)$ and $\mathrm{M}_{3}$ $(50 \%)$ were more variable. The metrical analysis revealed several significant differences in tooth size among the peoples of Micronesia. The teeth from Palau and Kiribati were usually larger than those from the Marshall Islands and Guam. The teeth of Native Australians are generally the largest in the Pacific.

The dental evidence suggested that the precontact people living on the small atolls and coral islands in the eastern areas of Micronesia were in many ways dentally similar to the modern day Yapese who were found to be dentally more closely affiliated with people to the east (Polynesia) than to the south (Melanesia) (Harris and others, 1975).
\end{abstract}

Keywords: Tooth morphology, Odontometrics

Corresponding author: Daris R. Swindler

1212 8th Ave. North Edmonds, WA 98020, USA

E-mail: dswindle@u.washington.edu 


\section{Introduction}

Micronesia is anything but a homogeneous culture area and the vastly different island types (high volcanic, raised limestone, and low coral atolls) and numerous external influences occurring throughout nearly four millennia of human occupation have given rise to a range of cultural diversity spread across the $4300 \mathrm{~km}$ region. While western Micronesia was settle, in part, from the Philippines and central Micronesia from island groups to the south, eastern Micronesia experienced significant interaction with Polynesia (Intoh, 1997; Irwin, 1992; Weisler, 1999b). Indeed, as suggested by the distribution of mtDNA, languages, and artifact studies, the post colonization histories of Micronesia are highly complex (Ayres and others, 1997, Figure 4.1; Intoh, 1997; Lum, 1998; Weisler and others, 2000). Human biological characteristics, when compared across the region, provide another independent avenue for examining microevolutionary mechanisms such as the founders effect, genetic drift, genetic bottlenecks, and selection. The purpose of this paper is to describe and compare the teeth of precontact Marshallese with the teeth of contemporary Micronesians in the hope of better understanding the dental relations existing among them as well as with other Pacific peoples.

Forming the eastern border of Micronesia, the Marshall Islands consist of 29 coral atolls and 5 raised coral islands (land area of $181 \mathrm{~km}^{2}$ ) forming two parallel island chains stretching more or less north and south (Figure 1). The islands have been occupied at least since 2000 B.P. according to dates from Bikini, Maloelap, Kwajalein, and Ebon atolls (Riley, 1987; Shun and Athens, 1990; Streck, 1990; Weisler, 1999a). Based on recent research, post colonization contacts are suggested with Polynesia and perhaps as far west as the Marianas (Weisler and others, 2000). Other major migrations into the Marshall Islands may have come from island groups (such as the Solomon Islands) to the southwest (Intoh, 1997).

\section{Materials and Methods}

The Marshall Islands dental material, including both deciduous and permanent teeth, came from precontact sites on six atolls. The most northern study location is Utrik Atoll, while Kwajalein, Majuro, Maloelap, and Ujae atolls are in the middle of the archipelago and Ebon Atoll is the southern most location (Figure 1). All dental material was collected by MIW, except that from Majuro which was acquired by Spennemann (1994) during salvage archaeological excavations in 1989 and include both deciduous and permanent teeth. The most southern location is Ebon Atoll, while Kwajalein, Majuro, and Ujae Atoll are in the middle of the archipelago and Utrik Atoll is the most northern location. All dental material was collected by MIW, except that from Majuro which was excavated by Spennemann (1994) during salvage archaeological excavations in 1989.

The Utrik dental material consist of teeth from an extended adult burial of a female aged 25-40 years old at the time of death. Although, not directly dated, the burial is from a major habitation site dated to 1860 to 380 B.P. (Weisler, unpublished). The Majuro Atoll collection comes from a prehistoric cemetery at Laura village, located on 

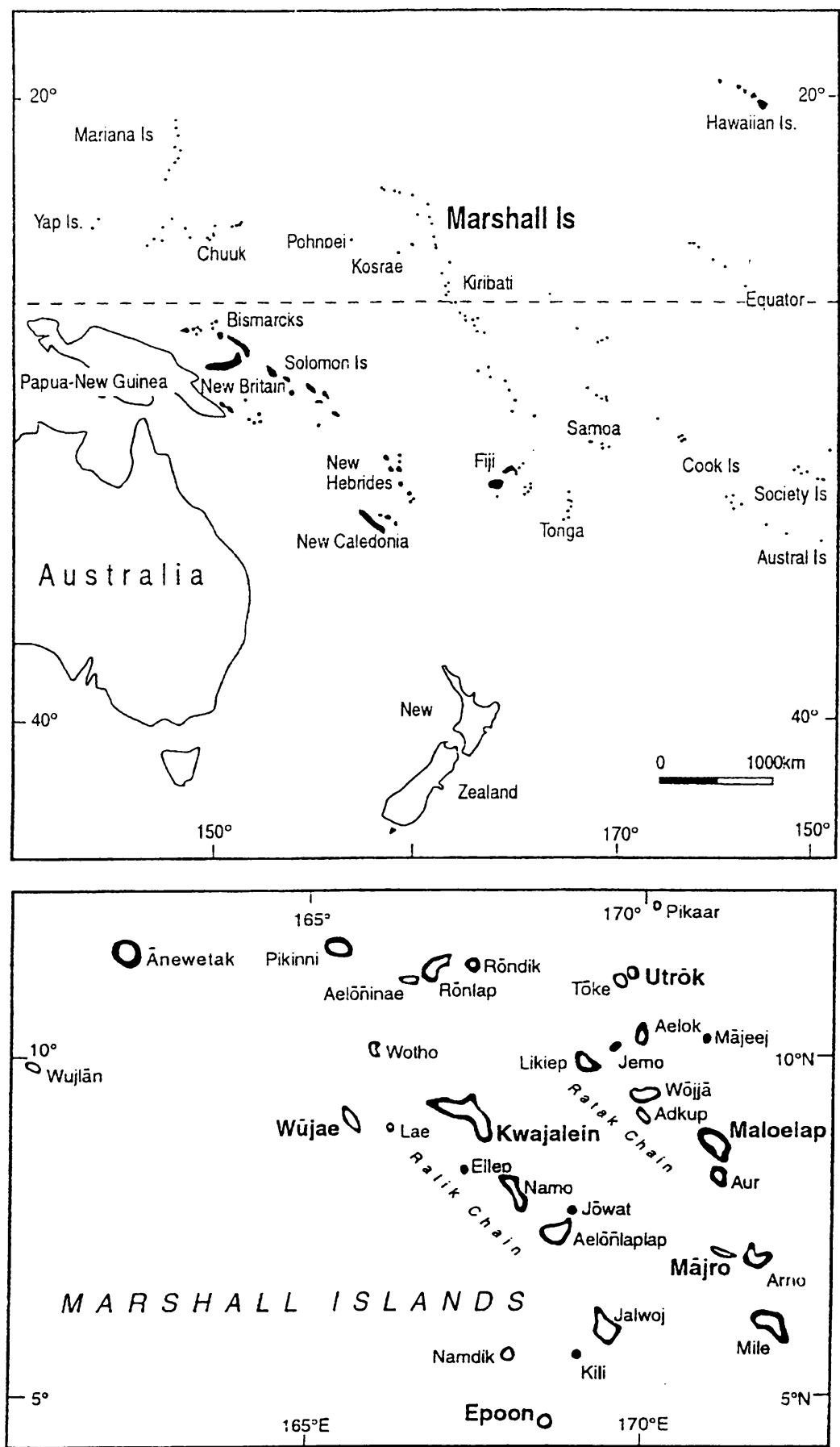

Figure 1 Map of Micronesia showing the location of the Marshall Islands. Dental material used in this study came from atolls highlighted in bold: Utrōk (Utrik), Wūjae (Ujac), Kwajalein, Maloelap, Mājro (Majuro), and Epoon (Ebon). 
the largest islet at the western end of the atoll. Twenty-nine burials were excavated in a salvage operation hurriedly undertaken in 1989 prior to development of a water system (Spennemann, 1994). Some 631 shell artifacts were found associated with 12 burials, three of which produced radiocarbon age determinations calibrated to the 2 nd to 7 th centuries A.D. (Weisler, 1999a). From Ujae Atoll, dental remains are from what appears to be a small family cemetery radiocarbon dated to between the 3rd and 6th centuries A.D. (Weisler, 1999b). Recovered from about $1.25 \mathrm{~m}$ below surface in a $1 \mathrm{~m}^{2}$ excavation unit where the fragmentary bones and whole teeth of at least four individuals. The Kawajalein collection is from a single male burial aged 30 to 40 years at the time of death. The individual was directly dated producing a mean calibrated radiocarbon age determination of A.D. 1486 (Weisler and others, 2000). The Maloelap dental material consists of two isolated teeth found $53-74 \mathrm{~cm}$ below surface in a habitation site. The closest radiocarbon age determination is nearly 2000 B.P., but is $50 \mathrm{~cm}$ deeper in an adjacent unit. The teeth, however, are clearly prehistoric. From Ebon Atoll, the dental remains are from discrete, but disturbed burials from two habitation sites dated to between the 1 st and 15 th centuries A.D. (Weisler, unpublished).

\section{Dental dimensions permanent teeth}

Crown length, the maximum mesiodistal dimension on the occlusal surface of the tooth.

Crown breadth, the maximum buccolingual dimension perpendicular to the length.

Crown height, the distance between the tip of the cusp (mesiobuccal cusp on premolars and molars) and the cementoenamel junction.

Root length, the distance between the root apex (mesiobuccal root on premolars and molars) and the cementoenamel junction.

One investigator, DRS, made all measurements and observations. The measurements were taken to $0.01 \mathrm{mms}$ using a Mitutoyo caliper. No attempt was made to separate the teeth by sex since many were isolated or in jaw fragments. Teeth showing enough wear or pathology to decrease their original dimensions were not measured. An analysis of variance (ANOVA) was performed on the odontometric material to test for any significant differences among the four Micronesian groups used in this part of the study. These results are presented as the F-statistic and its P-value at the bottom of Tables 13-16.

\section{Dental morphology of permanent teeth}

Morphological observations followed the procedures of Turner and others (1991). The following quasi-continuous dental traits were recorded: shoveling of the upper central and lateral incisors, Carabelli's trait of maxillary molars, cusp numbers of the maxillary molars, enamel pearls on molars, cusp numbers and groove patterns of mandibular molars, deflecting wrinkle on $\mathbf{M}_{1}$, protostylid, 6th cusp, 7th cusp, and three-rooted $\mathbf{M}_{1}$. Pearson Chi-square values were calculated for all morphological observations and adjusted residuals from each chi-square test were then calculated. The significant residuals (significant at $\mathrm{P}=0.05$ or less) are discussed in the text under the various dental traits presented in 
Tables 1-9.

\section{Results and Disccusion}

The maxillary central and lateral incisors may have a configuration known as "shoveling" which is more common on the lingual than on the labial surface of the tooth. Shoveling results from a thickening of the mesial and distal marginal ridges with a commensurate depression on the lingual surface of the crown. It is generally accepted today that the trait is more common and more strongly expressed in Asian populations than in other groups of humankind, although there may be some development of the trait in all populations. Hrdlicka (1920) first proposed a scaling system for defining the trait from absent to full development. More recently Turner and others (1991) proposed an expanded classification, absent (0) to marked shovel (6), which we have collapsed into four categories for comparison with other studies (Tables 1 and 2).

Shovel-shaped incisors are compared in various Pacific populations in Tables 1 and 2. It is immediately apparent that the presence of the marked development of shoveling is rare among Pacific peoples. Indeed, marked shoveling is found only in Samoa above $10 \% ; 18.8 \% \mathrm{I}^{1}$ and $17.0 \% \mathrm{I}^{2}$ (Tables 1 and 2); both of these are significantly different from all other populations at $\mathrm{P}=0.05$. Suzuki and Sakai (1964) also found occasional double shovel-shaped upper incisors. Of these ten groups, the Fiji islanders possessed significantly fewer shovel-shaped incisors $(\mathrm{P}=0.05)$. It is interesting to note that Snow (1974)stated that the early Hawaiians from Mokapu possessed many shovel-shaped incisors. Unfortunately, his analysis identified shoveling only as "to medium and marked degree" and combined $\mathrm{I}^{1}$ and $\mathrm{I}^{2}$ listing males as having $20 \%$ and females $24 \%$. In his examination of 47 ancient Hawaiian skulls with incisors, Chappel (1927) described 28 males having shoveling in a medium degree. Of 19 female skulls, two had well marked shovel-shaped incisors. It would seem that the degree of shoveling has not changed appreciably in Polynesia since precontact times except for the increase in marked shoveling in Samoa.

Regarding Micronesia, when shoveling is present, it is almost always either trace or semi-shoveling and this is seemingly the situation in precontact as well as recent populations (Tables 1 and 2). Levy (1981, p. 245) also reported "low grades of shoveling" for precontact Marianas. Polynesia is not too different from Micronesia except for the higher incidence of marked shoveling in the Polynesian groups $(\mathrm{P}=0.05)$ studied by Suzuki and Sakai (1964) and Riesenfeld (1956). Also, both Polynesia and Micronesia have a somewhat higher frequency of semi-shoveling than is found in Melanesia and Australia where full shoveling is apparently absent (Tables 1 and 2). Shoveling is considered more common in the Sinodont than the Sundadont division of the Mongoloid dental complex (Turner, 1990a). Since Turner considers a semishovel to marked shovel (grades 3-6) to represent shoveling in this classification, the precontact Marshallese with 33\% semishovel are considered Sinodont. Double-shoveling was not present in this sample of Marshallese. For one of the most complete analyses of shoveling and its worldwide distribution, see 
Table 1 Shovel-shaped upper I1 variation in the Pacific (\%)

\begin{tabular}{lrrrrrl}
\hline Group & N & None & Trace & Semi & Full & Source \\
\hline Marshallese & 12 & 8.3 & 58.4 & 33.3 & - & Present study \\
Yapese & 24 & 37.5 & 41.7 & 20.8 & - & Harris and others, 1975 \\
Micronesia & 143 & 22.0 & 43.0 & 31.0 & 4.0 & Riesenfeld, 1956 \\
Polynesia & 80 & 21.0 & 45.0 & 26.0 & 8.0 & Riesenfeld, 1956 \\
Polynesia (Samoa) & 96 & 24.0 & 33.3 & 24.0 & 18.8 & Suzuki and Sakai, 1964 \\
Easter Is. & 118 & 12.7 & 59.3 & 24.6 & 3.4 & Turner and Scott, 1977 \\
Fiji & 892 & 52.0 & 34.0 & 12.0 & 2.0 & Riesenfeld, 1956 \\
Solomon Is. & 109 & 26.6 & 55.1 & 16.5 & 1.8 & Bailit and others, 1968 \\
West Nakanai & 46 & 43.5 & 50.0 & 6.5 & - & Turner and Swindler, 1978 \\
Australia & 47 & 36.0 & 51.0 & 13.0 & - & Riesenfeld, 1956 \\
\hline
\end{tabular}

Note: Riesenfeld combined upper I1 and I2. Sexes pooled in all cases except W. Nakanai (males).

Table 2 Shovel-shaped upper 12 variation in the Pacific (\%)

\begin{tabular}{lrrccrl}
\hline Group & N & None & Trace & Semi & Full & Source \\
\hline Marshallese & 10 & 10.0 & 70.0 & 20.0 & - & Present study \\
Yapese & 23 & 17.4 & 60.9 & 21.7 & - & Harris and others, 1975 \\
Polynesia (Samoa) & 87 & 28.0 & 30.0 & 25.0 & 17.0 & Suzuki and Sakai, 1964 \\
Easter Is. & 124 & 6.5 & 65.3 & 24.4 & 4.0 & Turner and Scott, 1977 \\
Solomon Is. & 110 & 34.6 & 50.0 & 14.6 & 0.9 & Bailit and others, 1968 \\
West Nakanai & 46 & 52.5 & 46.5 & - & 2.0 & Turner and Swindler, 1978 \\
\hline
\end{tabular}

Sexes pooled in all cases except W. Nakanai (males).

Mizoguchi (1985).

Carabelli's trait is a feature on the lingual surface of the protocone of permanent upper molars with its strongest expression on $\mathbf{M}^{1}$ and it may also be present on the deciduous $\mathrm{dm}^{2}$. Carabelli's trait is graded from $0=$ total absence to $7=$ a large cusp with free apex (Turner and others, 1991). The trait is usually thought to represent a European dental marker trait but a recent exhaustive survey (29,000 individuals representing 15 geographic regions) by Turner and Hawkey(1998) has shown that, by itself, Carabelli's trait (grade 2=pit to 7=large free cusp) is not a European marker trait. It occurs in $43 \%$ of Europeans which is the same or less than percentages for North American Indians, Africans, and Micronesians (Turner and Hawkey, 1998). Even when using only the cusp expression (5-7) it is not distinctive of Europeans who have $13.9 \%$ since this percentage is lower than many other regions of the world, for example, North Asia (16.0\%), Polynesia (17.0\%), Africa (20.4\%), Micronesia (22.9\%), Near/Middle East (32.7\%), and is just higher than Southeast Asia (12.2\%) (Turner and Hawkey, 1998).

The frequency of Carabelli's trait on $\mathbf{M}^{1}$ in the Pacific is shown in Table 3. If we compare these incidences (grades 2-7) with those of Turner and Hawkey (1998) for the 
same geographical regions, namely Polynesia (30.8\%), Micronesia (39.0\%), Melanesia (34.6\%) and Australia (26.1\%), the major difference is the high percentage reported by Barksdale (1972) for the Eastern Highlands of New Guinea which is different from the other groups at the $\mathrm{P}=0.05$. It should be mentioned; however, that the most common expression of Carabelli's trait reported by Barksdale was the groove pattern (41\%). In the Pacific, as in the world at large, Carabelli's trait exhibits a wide range of inter and intra-regional variation and should be used with discretion when attempting to sort out genetic relationships.

The hypocone of upper molars expresses some size reduction from $\mathbf{M}^{1}$ to $\mathbf{M}^{3}$ in all human populations. The morphogenetic field is strongest on $\mathbf{M}^{1}$, less on $\mathbf{M}^{2}$, and least on $\mathbf{M}^{3}$, as depicted in Table 4. The hypocone is generally present on $\mathbf{M}^{1}$ in most populations but may be absent in Native Australians and the Nasioi of the Solomon Islands (Table 4). As predicted by the morphogenetic field theory, $\mathbf{M}^{2}$ is more variable and, of the eight groups shown in Table 4, only the precontact Marshall Islanders and the living Yapese had a hypocone on all $\mathrm{M}^{2}$ s that is significant from the Living Easter Islanders and the Solomon Islanders at the $\mathrm{P}=0.05$ level. The hypocone is always more variable on $\mathbf{M}^{3}$ (Table 4), but is only significantly more often absent on Living Easter Islanders and Solomon Islanders $(\mathrm{P}=0.05)$ than on other Pacific Islanders. With respect to Micronesia, there is no significant difference in the expression of the hypocone between the precontact Marshallese and the living Yapese.

The arrangement of the grooves and cusps on the mandibular molars of hominoids have been widely studied since the early investigations of Gregory (1916) and Gregory and Hellman (1926). The different patterns are designated Y5, Y4, +5, +4, and X depending on the number of cusps and the arrangement of the grooves separating the cusps on the occlusal surface of the molars. The Y5 or Dryopithecus pattern is an old arrangement phylogenetically and has been present in hominoids since the Miocene. As in the upper molars, $M_{1}$ is the most conservative of the lower molars retaining a high

Table 3 Carabelli's trait on upper M1 in the Pacific (\%)

\begin{tabular}{lrll}
\hline Group & N & M1 & Source \\
\hline Marshallese & 18 & 39 & Present study \\
Yapese & 24 & 29 & Harris and others, 1975 \\
Guam (Precontact) & 89 & 12 & Leigh, 1929 \\
Easter Is. (Precont) & 52 & 29 & Swindler and others, 1998 \\
Living Easter Is. & 105 & 33 & Turner and Scott, 1977 \\
W. Nakanai & 45 & 46 & Turner and Swindler, 1978 \\
New Guinea & 206 & 74 & Barksdale, 1972 \\
Nasioi (Solomons) & 134 & 20 & Bailit and others, 1968 \\
Australia & 30 & 33 & Smith and others, 1981 \\
\hline
\end{tabular}

Sexes pooled except W. Nakanai (males only). 
Table 4 Prescence of maxillary molar hypocones in the Pacific (\%)

\begin{tabular}{lccll}
\hline Group & M1 & M2 & M3 & Source \\
\hline Marshallese & $100(18)$ & $100(13)$ & $83(6)$ & Present study \\
Yapese & $100(24)$ & $100(23)$ & $80(5)$ & Harris and others, 1975 \\
Precontact Easter Is. & $100(52)$ & $98(23)$ & $80(40)$ & Swindler and others, 1998 \\
Living Easter Is. & $100(107)$ & $78(141)$ & $44(63)$ & Turner and Scott, 1977 \\
New Guinea & $100(200)$ & $95(204)$ & $92(144)$ & Barksdale, 1972 \\
West Nakanai & $100(45)$ & $88(43)$ & $80(24)$ & Turner and Swindler, 1978 \\
Solomon Is. & $99(134)$ & $70(106)$ & $45(49)$ & Bailit and others, 1968 \\
Australia & $95(40)$ & $96(29)$ & $82(22)$ & Smith and others, 1981 \\
\hline
\end{tabular}

Sexes pooled in all cases except W. Nakanai (males only). Numbers in parentheses are sample size.

frequency of the Y5 pattern in human populations while $\mathrm{M}_{2}$ and $\mathrm{M}_{3}$ are frequently modified into + and $\mathrm{X}$ patterns with reduction of cusp numbers from five to four, particularly on $\mathrm{M}_{3}$.

The various manifestations of the lower molar patterns in the Pacific are shown in Tables 5, 6, and 7. Table 5 displays the high incidence of the Y5 pattern followed by the +5 pattern which indicates the high frequency of five cusps on $\mathrm{M}_{1}$. Of the nine groups in Table 5, the Solomon Islanders possess the lowest incidence of Y5 patterns followed by the peoples from the eastern highlands of New Guinea, and both are significantly different from the other populations $(\mathrm{P}=0.05)$. The +5 pattern is more frequent in Solomon Islanders than in the other groups at the $\mathrm{P}=0.05$ level of significance while the $\mathrm{X}$ pattern is present only in the Yapese, and both Precontact and Living Easter Islanders and it is significantly different $(\mathrm{P}=0.05)$ from the other groups. In contrast, Tables 6 and 7 show the reduction of the Y5 pattern and the increase of pattern variability on $\mathrm{M}_{2}$ and especially, $\mathrm{M}_{3}$. The $\mathrm{X}$ groove pattern (contact between the protoconid and entoconid) represents the most modified arrangement from the $\mathrm{Y}$ configuration (contact between the metaconid and hypoconid) and was first described by Jorgensen (1955). This pattern increases in frequency from $\mathrm{M}_{1}$ to $\mathrm{M}_{3}$ in most Pacific populations with the exception of native Australians where it is absent on $\mathrm{M}_{1}$ and $\mathrm{M}_{3}$ with only a $4 \%$ frequency on $\mathrm{M}_{2}$ (Tables 5, 6, and 7). The native Australian is the only population lacking the $\mathrm{X}$ pattern on $\mathrm{M}_{3}$ and it is significantly different $(\mathrm{P}=0.05)$ from all other groups regarding this trait (Table 7).

Four-cusped lower second molars occur when the hypoconulid or 5th cusp is completely absent. As seen in Table 8, there are many regional differences in the geographic distribution of this trait in the Pacific. The trait is distinctive of Melanesian groups where it is significantly different $(\mathrm{P}=0.05)$ from other populations. It is significantly lower $(\mathrm{P}=$ 0.05 ) in native Australians than the other groups, and only slightly higher in Micronesians and Polynesians except for Easter Islanders, especially living Easter Islanders (53\%). 
Table 5 Mandibular occlusal patterns of M1 in the Pacific (\%)

\begin{tabular}{|c|c|c|c|c|c|c|}
\hline Group & Y5 & Y4 & +5 & +4 & $\mathrm{X}$ & Source \\
\hline Mairshallese & $90(20)$ & & $5(20)$ & $5(20)$ & & Present study \\
\hline Yapese & $90(22)$ & & & & $10(22)$ & Harris and others, 1975 \\
\hline West Samoa & $82(170)$ & & $16(170)$ & $2(170)$ & & Suzuki and Sakai, 1973 \\
\hline PreEaster Is. & $80(61)$ & & $8(61)$ & & $12(61)$ & Swindler and others, 1998 \\
\hline LivEaster Is. & $87(42)$ & & $6(42)$ & & $7(42)$ & Turner and Scott, 1977 \\
\hline Solomon Is. & $55(113)$ & & 45 (113) & & & Bailit and others, 1968 \\
\hline New Guinea & $60(108)$ & $5(108)$ & $26(108)$ & $9(108)$ & & Barksdale, 1972 \\
\hline West Nakanai & $93(41)$ & & $7(41)$ & & & Turner and Swindler, 1978 \\
\hline Australia & $86(21)$ & & $5(21)$ & $9(21)$ & & Smith and others, 1981 \\
\hline
\end{tabular}

Sexes pooled except W. Nakanai (males only). Numbers in parentheses are sample size.

Table 6 Mandibular occlusal patterns of M2 in the Pacific (\%)

\begin{tabular}{lrccccl}
\hline Group & Y5 & Y4 & +5 & +4 & X & Source \\
\hline Marshallese & $43(14)$ & & $28(14)$ & $28(14)$ & & Present study \\
Yapese & $8(24)$ & & $25(24)$ & & $66(24)$ & Harris and others, 1975 \\
West Samoa & $9(79)$ & $1(79)$ & $53(79)$ & $37(79)$ & & Suzuki and Sakai, 1973 \\
PreEaster Is. & $28(51)$ & $2(51)$ & $10(51)$ & $13(51)$ & $49(51)$ & Swindler and others, 1998 \\
LivEaster Isl. & $11(45)$ & & $19(45)$ & $19(45)$ & $51(45)$ & Turner and Scott, 1977 \\
Solomon Is. & $13(99)$ & & $87(99)$ & & & Bailit and others, 1968 \\
New Guinea & & $4(195)$ & $9(195)$ & $74(195)$ & $12(195)$ & Barksdale, 1972 \\
West Nakanai & $8(37)$ & & $68(37)$ & & $24(37)$ & Turner and Swindler, 1978 \\
Australia & & $4(23)$ & $88(23)$ & $4(23)$ & $4(23)$ & Smith and others, 1981 \\
\hline
\end{tabular}

Sexes pooled except W. Nakanai (males only). Numbers in parentheses are sample size.

Table 7 Mandibular occlusal patterns of M3 in the Pacific (\%)

\begin{tabular}{lcccccl}
\hline Group & Y5 & Y4 & +5 & +4 & X & \multicolumn{1}{c}{ Source } \\
\hline Marshallese & $50(8)$ & & $13(8)$ & & $38(8)$ & Present study \\
Yapese & $22(9)$ & & $11(9)$ & & $66(24)$ & Harris and others, 1975 \\
PreEaster Is. & $11(27)$ & $4(27)$ & $11(27)$ & $22(27)$ & $52(27)$ & Swindler and others, 1998 \\
LivEaster Is. & & & $15(26)$ & & $85(26)$ & Turner and Scott, 1977 \\
Solomon Is. & $7(42)$ & & $81(42)$ & & $12(42)$ & Bailit and others, 1968 \\
New Guinea & $3(129)$ & $1(129)$ & $36(129)$ & $24(120)$ & $32(129)$ & Barksdale, 1972 \\
West Nakanai & & & $22(27)$ & & $78(27)$ & Turner and Swindler, 1978 \\
Australia & & $5(20)$ & $85(20)$ & $10(20)$ & & Smith and others, 1981 \\
\hline
\end{tabular}

Sexes pooled except W. Nakanai (males only). Numbers in parentheses are sample sizes.

Turner (1990a, p. 314) states that the "four cusped lower second molars have a generally higher frequency in Sundadont than in Sinodont peoples." The precontact Marshallese $(21 \%)$ are perhaps slightly more Sinodont with respect to this feature.

The sixth cusp appears between the entoconid and hypoconulid and grades in size 
from a small cusplet to a cusp larger than the hypoconulid. It may be present on all three lower molars and the percentages shown in Table 9 represent the pooled grades for each molar. The sixth cusp has a checkered distribution in human populations and according to Turner (1970), some of the largest examples and the highest percentages of the cusp are found in the Pacific.

As shown in Table 9 most Pacific groups have moderate to high frequencies of the sixth cusp with two exceptions: natives from the eastern highlands of New Guinea and the Nasioi from the Solomon islands have exceptionally low frequencies; indeed, the lowest reported in the Pacific. Both of these populations are significantly different $(\mathrm{P}=0.05)$ on all three molars from the other Pacific groups. Although not in Table 9, since no statistics

Table 8 Four cusped mandibular M2's in the Pacific (\%)

\begin{tabular}{lcl}
\hline Group & M2 & Source \\
\hline Marshallese & $21(14)$ & Present study \\
Yapese & $13(23)$ & Harris and others, 1975 \\
Guam & $15-$ & Turner and Swindler, 1978 \\
West Samoa & $23(79)$ & Suzuki and Sakai, 1973 \\
Hawaii & $18-$ & Turner and Swindler, 1978 \\
PreEaster Is. & $37(51)$ & Swindler and others, 1998 \\
LivEaster Is. & $53(45)$ & Turner and Scott, 1977 \\
Solomon Is. & $71(103)$ & Bailit and others, 1968 \\
New Guinea & $70(195)$ & Barksdale, 1972 \\
West Nakanai & $46(37)$ & Turner and Swindler, 1978 \\
Australia & $8(20)$ & Smith and others, 1981 \\
\hline
\end{tabular}

Sexes pooled except West Nakanai (males only).

Numbers in parentheses are sample size.

Table 9 Six cusped mandibular molars in the Pacific (\%)

\begin{tabular}{lcccl}
\hline Group & M1 & M2 & M3 & Source \\
\hline Marshallese & $55(20)$ & $21(14)$ & $50(8)$ & Present study \\
Yapese & $70(24)$ & $77(22)$ & $80(10)$ & Harris and others, 1975 \\
West Samoa & $55(507)$ & $30(367)$ & $50(8)$ & Suzuki and Sakai, 1973 \\
PreEaster Is. & $35(42)$ & $10(51)$ & $14(27)$ & Swindler and others, 1998 \\
LivEaster Is. & $20(46)$ & $9(84)$ & $14(63)$ & Turner and Scott, 1977 \\
Solomon Is. & $31(125)$ & $2(103)$ & $4(50)$ & Bailit and others, 1968 \\
New Guinea & $7(199)$ & $2(175)$ & $6(129)$ & Barksdale, 1972 \\
West Nakanai & $30(41)$ & $10(41)$ & $34(32)$ & Turner and Swindler, 1978 \\
Australia (1) & $66(316)$ & $50(271)$ & $33(15)$ & Townsend and others, 1990 \\
Australia (2) & $65(23)$ & $47(19)$ & $33(15)$ & Smith and others, 1981 \\
\hline
\end{tabular}

Australia (1) Yuendumu Australia (2) Broadbeach

Sexes pooled except West Nakanai (males only).

Numbers in parentheses are sample size. 
are presented, Levy (1981) reports a low frequency of C6 in precontact Marianas. It is also interesting to note that both the precontact and living Easter islanders at the eastern edge of Polynesia possess moderate to low frequencies. In contrast to other Pacific groups, the Yapese possess quite high frequencies on all three lower molars, especially $\mathrm{M}_{3}$. This incidence is significantly different $(\mathrm{P}=0.05)$ from the frequency in the Marshallese. Native Australians have high frequencies on $M_{1}$ but are reduced on $M_{2}$ and, especially $M_{3}$. There is no clear ordering of the frequency of $\mathrm{C} 6$ on the three molars, in general $\mathrm{M}_{1}$ has more C6's than $M_{2}$ while $M_{3}$ tends to have more than $M_{2}$ thus $M_{1}>M_{2}<M_{3}$.

Another extra cusp that is occasionally found on lower molars between the metaconid and entoconid is known as the seventh cusp (C7). It is less frequent than C6 in most populations and only occurs twice in the Marshallese, once on $M_{1}$ out of twenty $M_{1}$ 's and once on $\mathrm{M}_{2}$ out of fourteen $\mathrm{M}_{2}$ 's. Its highest frequency in the Pacific is found in the Yapese $\left(\mathrm{M}_{1} 30 \%, \mathrm{M}_{2} 12 \%, \mathrm{M}_{3} 20 \%\right.$, Harris, and others, 1975) and the living Easter Islanders $\left(\mathrm{M}_{1} 23 \%, \mathrm{M}_{2} 14 \%, \mathrm{M}_{3} \%\right.$, Turner and Scott, 1977).

The deflecting wrinkle, which may be present on the occlusal surface of $M_{1}$, is present in one $\mathrm{M}_{1}$ out of fifteen $\mathrm{M}_{1}$ 's while the three-rooted $\mathrm{M}_{1}$ is not present. According to Turner (1990a), both of these traits are more common in Sinodont populations. The three-rooted $\mathrm{M}_{1}$ is not common in Oceania ( $\left.<10 \%\right)$; although, it had an incidence of $28.8 \%$ in precontact Easter Islanders (Swindler and others, 1997).

A protostylid (paramolar cusp) is a rare trait occurring most commonly on $\mathbf{M}_{1}$ and $\mathbf{M}_{3}$. It appears on the buccal surface of the protoconid and has been graded on a scale of 1 = pit to 7 =cusp with a free apex (Turner and others, 1991). Minor grades but no cusps are reported in low frequency for the Yapese (Harris and others, 1975) while Turner and Scott (1977) found a $7 \%$ incidence of cusp formation on $\mathrm{M}_{1}$ and $18 \%$ on $\mathrm{M}_{3}$ in contemporary Easter Islanders. The West Nakanai had small cusps $(8 \%)$ on $\mathrm{M}_{3}$. In the present sample of precontact Marshallese, well formed cusps were present on two of $18 \mathrm{M}_{1}$ 's (11\%) and one of $16 \mathrm{M}_{3}$ 's $(6 \%)$. The highest frequencies of protostylids in Pacific Islanders have been reported by Snow (1974) for early Hawaiians (43\%) and Barksdale (1972) for the Eastern Highlands of New Guinea (42\%). Unfortunately, neither author mentioned which molars possessed the protostylid.

Enamel nodules or pearls are small enamel droplets that occasionally form a little below the neck between the roots of either upper or lower molars, albeit more common on the upper molars. They have been recorded in low frequencies in most human populations including Australians, Melanesians, Europeans, and Africans. Their greatest numbers have been found among the East Greenland Eskimo 27\% of 312 cases reported by Pedersen (1949). Of three well preserved maxillary molars from a Lapita site (1600-500 B.C.) on Mussau Island in Melanesia, one $\mathrm{M}^{2}$ had a well formed enamel pearl between its roots (Kirch and others, 1989). In the present sample, of six $\mathrm{M}^{3}$ 's, two had enamel nodules and of twenty $\mathrm{M}_{1}$ 's, one had an enamel nodule. There were a total of 79 molars of which $3.8 \%$ possessed enamel nodules. Enamel extensions may also be present on the buccal root surface of $\mathrm{M}^{1}$ extending for several millimeters along the root. There 
were no enamel extensions in the present sample. This trait is more frequent in Sinodont dentitions (Turner, 1990a).

There was a reduction in the size of M3 as noted by the absence of the hypocone (Table 4), but there were no peg-shaped M3 's which are somewhat more common in Sinodont dentitions (Turner, 1990a). Of fourteen $\mathrm{P}^{1}$ 's $79 \%$ had one root while $21 \%$ had two roots. The former condition is generally found more often in Sinodont dentitions (Turner, 1990a).

\section{Dental morphology of deciduous teeth}

It is well known that morphological variations of human deciduous teeth are as important for the study of biological relations among populations as those of the permanent teeth (Jorgensen, 1956; Kitagawa and others, 1995). Yet, the most thorough study of the human deciduous dentition is the monograph by Jorgensen (1956) which still remains, the single most authoritative investigation of human deciduous teeth.

There is scant material from the Pacific, and as far as we know, nothing from Micronesia except the few deciduous teeth discussed here. The deciduous teeth consisted of one $\mathrm{dm}^{1}$, four $\mathrm{dm}^{2}$ 's, and six $\mathrm{dm}_{2}$ 's. There were no $\mathrm{dm}_{1}$ 's and unfortunately, there were no anterior teeth.

Three of the four $\mathrm{dm}^{2}$ 's $(75 \%)$ possessed Carabelli's trait of which two were large cusps and one had a large Y-shaped depression. Hillson (1996) stated that Carabelli's trait occurs on both $\mathrm{dm}^{1}$ and $\mathrm{dm}^{2}$ but is more frequent on the latter tooth. It was not present on the single $\mathrm{dm}^{1}$ in the present sample. Jorgensen (1956) used three stages of development in his analysis of the trait on $\mathrm{dm}^{2}$ in Recent Danes $(1,346$ teeth) and found it present in some form on all $\mathrm{dm}^{2}$ s; however, no traces of the trait were found on $\mathrm{dm}^{1}$. In their study of the prehistoric Jomon people of Japan (Kitagawa and others, 1995) found $12.5 \%$ of the sample of 40 individuals with Carabelli's trait (grades 4-7).

Four of the six dm $\mathrm{dm}_{2}$ 's had C6 $(66.7 \%$ or Y-6). Two of these teeth possessed C7. The other two dm $\mathrm{m}_{2}$ 's had a Y-5 pattern, thus all dm $\mathrm{d}_{2}$ 's had a Y-5 or Y-6 cusp groove pattern. Cusp 6 is more frequent on $\mathrm{dm}_{2}$ than it is on the permanent molars in our small sample from the Marshall Islands. The only comparative material from the Pacific was that of Suzuki and Sakai (1973) from Western Samoa and Kitagawa and others (1995) of the prehistoric Jomon people of Japan. Suzuki and Sakai (1973) found that of $103 \mathrm{dm}_{2}$ 's, $54.4 \%$ possessed $\mathrm{C} 6$, and they stated that the marked variety of C6 was "notably more frequent in the deciduous molars" than in the permanent molars (Suzuki and Sakai, 1973, p. 311). These authors also found a very high frequency of C7 on the $103 \mathrm{dm}_{2}$ 's (72.8\%). Kitagawa and others (1995) reported a high incidence on $51 \mathrm{dm}_{2}$ 's of C6 (62.7\%) and on $44 \mathrm{dm}_{2}$ 's of $\mathrm{C} 7(68.2 \%)$ in the prehistoric Jomonese.

Regarding the morphology of $\mathrm{dm} 2$ in Danes, the Y-5 pattern was almost always present (one case in 1,140 lacked the hypoconulid); however, the presence of C6 was infrequent: only $2.7 \%$ in $251 \mathrm{dm}_{2}$ 's while the frequency of $\mathrm{C} 7$ was somewhat higher, $23.8 \%$ of $344 \mathrm{dm}_{1}$ 's (Jorgensen, 1956). 


\section{Odontometrics of permanent teeth}

It is obvious from the foregoing discussion that there have been few studies of the morphology of Micronesian teeth when compared with other Pacific regions. To our knowledge, there are even fewer odontometric investigations of Micronesian teeth. There are two excellent studies by T. Hanihara (1992 and 1993) which did not report the basic dental measurements for the Micronesian samples he studied since he utilized distance measures based on Q-mode correlation coefficients. Matsuno (1997) and Kanazawa and others (1998) presented dental measurements taken on dental casts from the Micronesian islands of Kiribati and Palau. In addition, Brace (1981) and Brace and others (1989) presented summary tooth size data for Guam but did not include the odontometrics for individual teeth. Recently, however, Hanihara (1998) presented a detailed investigation of the morpho-metric dental variation of several human populations including precontact Chamorros from Guam.

Tables 10-12 present the basic statistics of crown height, root length, and the relative root length index. The major difference among the groups presented in Table 12 is the relatively longer roots possessed by the teeth of the Australian aborigines compared with the other four groups. Unfortunately, there is little information on the variation of root length among human populations, although Kovacs (1971) suggested that differences between various zoological groups might prove significant.

Table 10 Tooth crown height in Marshallese $(\mathrm{mm})$

\begin{tabular}{crrrr}
\hline & N & M & S.D. & C.V. \\
\hline Maxillary & & & & \\
I1 & 6 & 11.5 & 0.77 & 6.7 \\
I2 & 8 & 10.7 & 0.44 & 4.1 \\
C & 8 & 11.2 & 1.00 & 8.9 \\
P3 & 7 & 8.7 & 0.63 & 7.2 \\
P4 & 6 & 8.1 & 0.44 & 5.4 \\
M1 & 15 & 7.6 & 0.56 & 7.4 \\
M2 & 8 & 7.7 & 0.70 & 9.1 \\
M3 & 5 & 8.3 & 0.94 & 11.3 \\
Mandibular & & & & \\
I1 & 1 & 8.6 & - & - \\
I2 & 2 & 10.2 & - & - \\
C & 9 & 11.4 & 1.30 & 11.4 \\
P3 & 7 & 8.9 & 0.95 & 10.7 \\
P4 & 8 & 8.8 & 1.00 & 11.4 \\
M1 & 15 & 8.3 & 0.61 & 7.4 \\
M2 & 10 & 8.3 & 0.62 & 7.5 \\
M3 & 4 & 7.7 & 0.64 & 8.0 \\
\hline
\end{tabular}

Sexes pooled 
Table 11 Root length in Marshallese (mm)

\begin{tabular}{ccccc}
\hline & N & M & S.D. & C.V. \\
\hline Maxillary & & & & \\
I1 & 7 & 13.5 & 1.31 & 10.3 \\
I2 & 7 & 15.3 & 1.80 & 11.8 \\
C & 8 & 17.9 & 1.73 & 9.5 \\
P3 & 8 & 14.7 & 2.41 & 16.4 \\
P4 & 7 & 14.7 & 1.62 & 11.0 \\
M1 & 9 & 13.5 & 1.41 & 10.4 \\
M2 & 3 & 13.7 & 2.72 & - \\
M3 & 2 & 13.0 & - & - \\
Mandibular & & & & \\
I1 & 1 & 12.8 & - & - \\
I2 & 2 & 14.8 & - & - \\
C & 8 & 16.3 & 1.63 & 9.8 \\
P3 & 7 & 14.3 & 0.71 & 5.0 \\
P4 & 8 & 15.2 & 1.06 & 7.0 \\
M1 & 8 & 14.8 & 2.03 & 13.7 \\
M2 & 7 & 14.6 & 0.73 & 5.0 \\
M3 & 2 & 14.2 & - & - \\
\hline
\end{tabular}

Sexes pooled

Table 12 Relative root length index: root $\mathrm{lg} /$ total ld (\%). Sexes pooled

\begin{tabular}{cccccc}
\hline & Marshallese & Austral. (1) & Japan (2) & Am.White (3) & Easter Isl (PC)(4) \\
\hline Maxillary & & & & & \\
I1 & 54.0 & 60.0 & 53.9 & 59.1 & \\
I2 & 58.9 & 63.7 & 53.9 & 59.1 & \\
C & 61.5 & 72.4 & 58.3 & 62.3 & \\
P3 & 62.8 & 72.1 & 58.1 & 60.2 & \\
P4 & 64.5 & 75.8 & 62.3 & 65.1 & \\
M1 & 64.0 & 69.2 & 65.3 & 63.5 & 61.9 \\
M2 & 64.0 & 69.4 & 66.7 & 65.0 & 62.6 \\
M3 & 61.0 & 70.6 & 62.1 & 66.7 & 63.2 \\
Mandibular & & & & & \\
I1 & 59.8 & 63.8 & 50.5 & 57.0 & \\
I2 & 59.2 & 60.0 & 54.5 & 60.2 & \\
C & 58.8 & 64.6 & 55.5 & 60.0 & \\
P3 & 61.6 & 72.1 & 56.7 & 64.8 & \\
P4 & 63.3 & 73.3 & 61.5 & 64.6 & \\
M1 & 64.1 & 64.8 & 62.7 & 62.9 & 64.6 \\
M2 & 63.8 & 67.6 & 61.4 & 65.2 & 64.8 \\
M3 & 64.8 & 73.7 & 61.0 & 64.5 & 65.3 \\
\hline
\end{tabular}

(1).(2).(3), Campbell, 1925

(4), Swindler and others, 1999 
The odontometric data for crown length and breadth for Micronesia are presented in Tables 13-16. The precontact Marshallese and Kiribati samples are from Eastern Micronesia while the Palau and Guam material comes from Western Micronesia. At present, there is no dental information from Central Micronesia. The results of the ANOVA analysis

Table 13 Micronesia mandibular mesiodistal tooth diameters in males $(\mathrm{mm})$

\begin{tabular}{lcccccccc}
\hline Group & I1 & I2 & C & P3 & P4 & M1 & M2 & M3 \\
\hline Marshalls 1. (N) & 1 & 1 & 1 & 9 & 7 & 9 & 21 & 14 \\
M & 5.7 & 6.4 & 7.1 & 7.6 & 7.9 & 12.1 & 11.8 & 11.7 \\
SD & - & - & - & 0.35 & 0.37 & 0.42 & 0.40 & 0.76 \\
Palau 2. (N) & 47 & 48 & 45 & 47 & 47 & 47 & 23 & - \\
M & 5.9 & 6.5 & 7.5 & 7.9 & 7.9 & 12.5 & 11.7 & - \\
SD & 0.36 & 0.35 & 0.49 & 0.53 & 0.53 & 0.63 & 0.57 & - \\
Kiribati 2. (N) & 48 & 49 & 50 & 50 & 50 & 45 & 46 & - \\
M & 5.8 & 6.4 & 7.5 & 7.6 & 7.8 & 12.3 & 11.7 & - \\
SD & 0.27 & 0.37 & 0.41 & 0.46 & 0.56 & 0.63 & 0.73 & - \\
Guam 3. (N) & 19 & 29 & 41 & 44 & 54 & 50 & 49 & 31 \\
M & 5.5 & 6.3 & 7.4 & 7.6 & 7.7 & 12.6 & 11.6 & 11.0 \\
SD & 0.34 & 0.44 & 0.54 & 0.45 & 0.44 & 0.61 & 0.75 & 0.87 \\
F & 7.03 & 1.71 & 2.18 & 4.23 & 1.44 & 4.26 & 0.38 & 4.75 \\
P & $<0.001$ & 0.168 & 0.094 & $<0.007$ & 0.233 & $<0.006$ & 0.767 & $<0.036$ \\
\hline
\end{tabular}

1.Present study 2.Kanazawa and others 1998 3.Brace, (Unpublished data)

Table 14 Micronesia mandibular buccolingual tooth diameters in males ( $\mathrm{mm}$ )

\begin{tabular}{lcccccccc}
\hline Group & I1 & I2 & C & P3 & P4 & M1 & M2 & M3 \\
\hline Marshalls 1. (N) & 1 & $\mathbf{1}$ & 9 & 7 & 9 & 21 & 14 & 9 \\
M & 6.7 & 7.0 & 7.9 & 8.6 & 8.8 & 10.8 & 10.5 & 10.6 \\
SD & - & - & 0.55 & 0.34 & 0.25 & 0.42 & 0.44 & 0.40 \\
Palau 2. (N) & 43 & 46 & 46 & 48 & 48 & 45 & 35 & - \\
M & 6.5 & 6.7 & 7.9 & 8.7 & 9.0 & 11.4 & 11.2 & - \\
SD & 0.43 & 0.42 & 0.58 & 0.60 & 0.54 & 0.53 & 0.56 & - \\
Kiribati 2. (N) & 42 & 46 & 49 & 50 & 50 & 46 & 48 & - \\
M & 6.7 & 7.0 & 8.6 & 8.6 & 9.0 & 11.2 & 11.4 & - \\
SD & 0.55 & 0.50 & 0.56 & 0.53 & 0.56 & 0.55 & 0.57 & - \\
Guam 3. (N) & 19 & 29 & 41 & 44 & 54 & 50 & 49 & 31 \\
M & 6.1 & 6.8 & 8.3 & 8.7 & 8.9 & 11.3 & 10.8 & 10.4 \\
SD & 0.40 & 0.36 & 0.54 & 0.66 & 0.54 & 0.50 & 0.55 & 0.54 \\
F & 6.94 & 3.71 & 13.63 & 0.34 & 0.67 & 6.90 & 15.35 & 1.06 \\
P & $<0.001$ & $<0.014$ & $<0.001$ & 0.797 & 0.571 & $<0.001$ & $<0.001$ & 0.310 \\
\hline
\end{tabular}

1. Present study 2. Kanazawa and others, 1998 3. Brace (Unpublished data) 
(the $\mathrm{P}$ value of the F-statistic) of the odontometric data are presented at the bottom of Tables 13-16.

There are several significant $\mathrm{P}$ values among the four groups suggesting a moderate amount of odontometric variability within Micronesia, albeit there are no apparent

Table 15 Micronesia maxillary mesiodistal tooth diameters in males (mm)

\begin{tabular}{lcccccccc}
\hline Group & $\mathrm{I} 1$ & $\mathrm{I} 2$ & $\mathrm{C}$ & $\mathrm{P} 3$ & $\mathrm{P} 4$ & $\mathrm{M} 1$ & $\mathrm{M} 2$ & $\mathrm{M} 3$ \\
\hline Marshalls 1. (N) & 10 & 11 & 10 & 13 & 10 & 18 & 13 & 6 \\
M & 8.6 & 7.0 & 8.1 & 7.7 & 7.5 & 10.9 & 10.3 & 9.9 \\
SD & 0.54 & 0.46 & 0.42 & 0.36 & 0.53 & 0.53 & 0.53 & 0.52 \\
Palau 2. (N) & 48 & 47 & 44 & 46 & 44 & 44 & 30 & - \\
M & 9.1 & 7.6 & 8.7 & 8.0 & 7.6 & 11.4 & 11.1 & - \\
SD & 0.51 & 0.46 & 0.58 & 0.47 & 0.47 & 0.62 & 0.72 & - \\
Kiribati 2. (N) & 48 & 49 & 50 & 50 & 50 & 50 & 46 & - \\
M & 8.8 & 7.2 & 8.6 & 7.7 & 7.4 & 11.0 & 10.6 & - \\
SD & 0.51 & 0.49 & 0.47 & 0.48 & 0.48 & 0.51 & 0.62 & - \\
Guam 3. (N) & 32 & 38 & 44 & 50 & 44 & 49 & 48 & 25 \\
M & 8.7 & 7.0 & 8.4 & 7.8 & 7.4 & 11.1 & 10.2 & 9.4 \\
SD & 0.52 & 0.64 & 0.45 & 0.48 & 0.41 & 0.47 & 0.69 & 0.89 \\
F & 5.58 & 10.88 & 5.53 & 3.67 & 1.90 & 5.92 & 12.11 & 1.72 \\
P & $<0.001$ & $<0.001$ & $<0.001$ & $<0.014$ & 0.132 & $<0.001$ & $<0.001$ & 0.200 \\
\hline
\end{tabular}

1. Present study 2. Kanazawa, and others 1998 3. Brace (Unpublished data)

Table 16 Micronesia maxillary buccolingual tooth diameters in males (mm)

\begin{tabular}{lcccccccc}
\hline Group & I1 & I2 & C & P3 & P4 & M1 & M2 & M3 \\
\hline Marshalls 1. (N) & 10 & 11 & 10 & 13 & 10 & 18 & 13 & 6 \\
M & 7.5 & 6.7 & 8.6 & 9.9 & 9.8 & 11.8 & 11.7 & 11.6 \\
SD & 0.34 & 0.38 & 0.51 & 0.79 & 0.46 & 0.57 & 0.56 & 0.45 \\
Palau 2. (N) & 43 & 44 & 46 & 48 & 47 & 45 & 30 & - \\
M & 7.6 & 7.1 & 8.6 & 10.1 & 10.0 & 12.1 & 12.5 & - \\
SD & 0.53 & 0.61 & 0.68 & 0.51 & 0.62 & 0.53 & 0.73 & - \\
Kiribati 2. (N) & 48 & 48 & 50 & 49 & 49 & 50 & 47 & - \\
M & 8.0 & 7.2 & 9.0 & 10.3 & 10.2 & 12.5 & 12.8 & - \\
SD & 0.65 & 0.41 & 0.53 & 0.51 & 0.68 & 0.63 & 0.69 & - \\
Guam 3. (N) & 32 & 38 & 44 & 50 & 44 & 49 & 48 & 25 \\
M & 7.9 & 7.1 & 9.0 & 10.1 & 10.0 & 12.2 & 12.1 & 11.8 \\
SD & 0.42 & 0.46 & 0.50 & 0.71 & 0.60 & 0.59 & 0.74 & 0.68 \\
F & 5.46 & 3.08 & 5.73 & 1.97 & 1.66 & 7.57 & 12.35 & 0.46 \\
P & $<0.001$ & 0.030 & $<0.001$ & 0.121 & 0.178 & $<0.001$ & $<0.001$ & 0.501 \\
\hline
\end{tabular}

1. Present study 2. Kanazawa, and others 1998 3. Brace, (Unpublished data) 
directional trends for example, east to west or west to east, in tooth size. Kanazawa and others (1998) do mention that mesiodistal diameters are "generally larger" in Palau than in Kiribati and the buccolingual dimensions in Kiribati are "slightly larger" than those in Palau. This same observation is true when the teeth of Palau and Kiribati are compared with the teeth from precontact Marshallese and Guam. The mesiodistal dimensions in Palau are somewhat larger than those in the Marshalls and Guam while the buccolingual dimensions in Kiribati are slightly larger than those in the Marshalls and Guam. It seems that the teeth from Palau, in western Micronesia, are longer, while the teeth from Kiribati, in eastern Micronesia, are wider, than teeth from other regions of Micronesia. It is interesting to note; however, that Howells (1973) and Pietrusewsky (1990) using cranial material, were able to separate western and eastern groups in Micronesia.

\section{Conclusions}

Shoveling of the maxillary incisors is most common in Asian peoples, particularly the marked variety. When observed in the Pacific, it is characteristically either trace or semi-shoveling except in Western Samoa where marked shoveling is present but still under $20 \%$.

Carabelli's trait is generally infrequent on $\mathrm{M}^{1}$ in Oceania except for some groups living in the Eastern Highlands of New Guinea who had 74\%; however, $41 \%$ of these were groove patterns. As with many quasi-continuous traits in the Pacific, Carabelli's trait exhibits a wide range of intra-regional variation.

The hypocone of maxillary molars expresses some size reduction from $\mathbf{M}^{1}$ to $\mathrm{M}^{3}$ in all populations. In the Pacific, $\mathbf{M}^{1}$ generally has some development of the hypocone although it is reported absent in native Australians and the Nasioi of the Solomon Islands. With respect to Micronesia, hypocone expression is almost identical between the precontact Marshallese and the living Yapese.

The arrangement of the cusps and grooves on the occlusal surface of the mandibular molars are designated $\mathrm{Y}-5, \mathrm{Y}-4,+5,+4$, and $\mathrm{X}$. The $\mathrm{Y}-5$ pattern is the most conservative and has its highest frequency in the Pacific on $\mathrm{M}_{1}$. In addition, the $\mathrm{X}$ pattern increases in frequency from $M_{1}$ to $M_{3}$ in most Pacific populations with the exception of native Australians.

The four-cusped $\mathbf{M}_{2}$ has its lowest frequency in native Australians and its highest incidence among Melanesians while Polynesians and Micronesians tend to be intermediate. Among Polynesians, it is higher in Easter Islanders. Higher frequencies of four-cusped M 2's are part of Turner's Sundadont dental classification (Turner, 1990a).

Cusp 6 appears on all three lower molars and the present tabulation of Pacific populations shows it most common in native Australians and Yapese while being very low in the Eastern Highlands of New Guinea. Cusp 7 appears less frequently than C6 on lower molars in the Pacific (only two cases in the present sample); however, its highest incidence in the Pacific is found in the Yapese.

The deflecting wrinkle is rare and three-rooted $\mathrm{M}_{1}$ 's are absent in the present sample 
of Marshallese. The protostylid occurs sporadically throughout the Pacific, generally less than $10 \%$, but it is common (42\%) in Eastern New Guinea and again, across the Pacific in Early Hawaiians (43\%). A well-formed protostylid occurs twice in the present sample, while of a total of 79 molars, $3.8 \%$ had enamel pearls.

A total of ten quasi-continuous dental traits were studied on the Marshallese teeth and compared with other Pacific island populations. It seems clear that there is quite a diversity in the traits represented throughout the Pacific and the various trait percentages suggest few directional indicators regarding migration routes. The traits exhibited in Micronesia may show similarities with groups to the east, for example, Carabelli's trait, while reduction of the hypocone is fairly similar throughout the Pacific. The mandibular occlusal patterns are more similar on $\mathrm{M}_{1}$ and $\mathrm{M}_{3}$ than they are on $\mathrm{M}_{2}$ among all groups. The frequencies of four-cusped $\mathrm{M}_{2}$ 's are more similar between Micronesians and Polynesians than between either Micronesians and Polynesians on the one hand and native Australians on the other. The incidence of C6 is very similar between the Marshallese and Western Samoa, but the Yapese frequency of $\mathrm{C} 6$ is the highest in the Pacific and more like the incidence in Melanesia and Australia, with the notable exception of the Eastern Highlands of New Guinea where it is the lowest in the Pacific.

Several years ago Turner (1990a) discussed eight morphological characters which defined the Sundadont and Sinodont divisions of the Mongoloid dental complex. The precontact Marshallese possess five features which are usually considered Sundadont: absence of the double-shovel on the upper incisors, low frequency of the deflecting wrinkle, no third root on $\mathbf{M}_{1}$, no development of an enamel extension on $\mathbf{M}^{1}$, and no evidence of peg-shaped $\mathrm{M}^{3}$. On the other hand, 33\% shoveling of $\mathrm{I}^{1}$ might suggest some Sinodont influence as well as the $21 \%$ of four-cusped $\mathrm{M}_{2}$. The high incidence $(79 \%)$ of one root $\mathrm{P}^{1}$ s is Sinodont. Thus, five of the eight traits align with the generalized Sundadont dentitions of Southeast Asia which adds support to the recent suggestions of T. Hanihara (1992 and 1993) that Micronesians, Polynesians, and Jomonese have lineages that can be traced back to a common gene pool in Southeast Asia as well as to Turner's (1990b, p. 403) findings suggesting that the Guamese dentition is morphologically most similar to Polynesians which originated in Southeast Asia and represents a "Polynesian-derived colonization of Micronesia."

There have been numerous migrations into Micronesia during the past two or three thousand years as well as inter-island movements of people within Micronesia throughout this long history (Ayres and others, 1997; Intoh, 1997; Weisler and others, 2000). The earliest migrations were to the Mariana islands along the western perimeter of Micronesia as early as 3600 B.P. The Marshall islands on the eastern boundary of Micronesia were peopled as recently as 2000 B.P. (Weisler, 1999a) and the dispersal routes into eastern Micronesia, as indicated by linguistic and artifactual evidence, came from the southwest (Athens, 1990a,b; Intoh, 1997; Weisler, 1999b). Such movement of small populations to formerly unoccupied islands (founders effect) followed by periods of temporary genetic isolation (genetic drift) which in turn are followed by more periods of contact (mixing) 
and subsequent isolation, offers a partial explanation for the type of dental diversity observable today in Micronesia as well as the Pacific in general.

\section{Acknowledgments}

Field work in the Marshall Islands (1993-1997) has been supported by generous grants to Weisler from: the Research Committee and the Division of Humanities, Divisional Research grant programs, University of Otago; the Historic Preservation Office, Republic of the Marshall Islands; the U.S. National Park Service;the Australian South Pacific Cultires Fund; the United Nations, International Year ot the World's Indigenous People Voluntary Fund; Mobil Oil Corporation of Micronesia. Certain individuals in the Marshall Islands deserve special mention: Dennis Alessio and family, Hemley Benjamin, Carmen Bigler, Irooj Lyang, Jackol Moore, Enta Peter, and Hemina Tarkio. At the University of Otago, thanks to Less O'Neill for preparing the figure. We wish to thank Dr. C. Loring Brace for permitting us to use his unpublished odontometric data from Guam.

\section{REFERENCES}

Athens J.S. (1990a) Nan Madol pottery, Pohnpei. Micronesica (Suppl.), vol. 2, pp. 17-32. Athens J.S. (1990b) Kosrac pottery clay, and early settlement. Micronesica (Suppl.), vol. 2, pp. 171-186.

Ayres W.S., Goles G.G., and Beardsley F.R. (1997) Provenance of lithic materials in Micronesia. In Weisler M.I. ed., "Prchistoric long-distance interaction in Oceania: an interdisciplinary approach”, New Zealand Archaeological Association Monograph 21, Auckland, pp. 53-67.

Bailit H.L., DeWitt S.J., and Leigh R.A. (1968) The size and morphology of the Nasioi dentition. American Journal of Physical Anthropology, vol. 28, pp. 271-287.

Barksdale J.T. (1972) A descriptive and comparative investigation of dental morphology. In Littlewood R.A. ed., "Physical Anthropology of the Eastern Highlands of New Guinea”, University of Washington Press, Seattle, pp. 113-174.

Brace C.L. (1981) Oceanic tooth-size variations as a reflection of biological and cultural mixing. Current Anthropology, vol. 22, pp. 549-569.

Brace C.L., Brace M.L., and Leonard W.R. (1989) Reflections on the face of Japan: A multivariate craniofacial and odontometric perspective. American Journal of Physical Anthropology, vol. 78, pp. 93-113.

Campbell T.D. (1925). Dentition and Palate of the Australian Aboriginal, Adelaide: The Hassel Press.

Chappel H.G., (1927) Jaws and Teeth of Ancient Hawaiians. Memoirs of the Bernice P. Bishop Museum, Honolulu, vol. 9, pp. 251-268.

Gregory W.K., (1916) Studies on the evolution of the primates. Bulletin of the American Muscum of Natural History, vol. 35, pp. 239-355.

Gregory W.K. and Hellman M. (1926) The Dentition of Dryopithecus and the origin of man. Anthropological Papers American Museum of Natural History, vol. 28, pp. 9-117. 
Hanihara T. (1992) Biological relationships among Southeast Asians, Jomonese, and the Pacific populations as viewed from dental characters: The basic populations in East Asia. Journal of the Anthropological Society of Nippon, vol. 100, pp. 53-68.

Hanihara T. (1993) Dental affinities among Polynesians and circum-Polynesian populations. Japan Review, vol. 4, pp. 59-82.

Hanihara T. (1998) Metric and nonmetric dental variations of major human populations. In J.R. Lukacs ed., "Human Dental Development, Morphology, and Pathology", University of Oregon Anthropological Papers, Eugene, No. 54, pp. 173-200.

Harris E.F., Turner C.G. II, and Underwood J.H. (1975) Dental morphology of living Yap islanders, Micronesia. Archaeology and Physical Anthropology in Oceania, vol. 10, pp. 218-234.

Hillson S. (1996) Dental Anthropology. Cambridge University Press, Cambridge.

Howells W.W. (1973) Cranial Variation in Man: A Study by Multivariate Analysis of Patterns of Difference among Recent Human Populations. Peabody Museum of Archaeology and Ethnology, Harvard University, Cambridge.

Hrdlicka A. (1920) Shovel shaped teeth. American Journal of Physical Anthropology, vol. 3, pp. 429-465.

Intoh M. (1997) Human dispersals into Micronesia. Anthropological Science, vol. 105, pp. $15-28$.

Irwin G. (1992) The Prehistoric Exploration and Colonization of the Pacific. Cambridge, Cambridge University Press.

Jorgensen K.D. (1955) The Dryopithecus pattern in recent Danes and Dutchman. Journal of Dental Research, vol. 34, pp. 195-208.

Jorgensen K.D. (1956) The deciduous dentition, a descriptive and comparative anatomical study. Acta Odontologica Scandinavica, vol. 14, pp. 7-191.

Kanazawa E. Matsuno M., Nakabayashi T., Igarashi Y., and Matsudo A. (1998) Tooth size of living peoples in Western and Eastern Micronesian Populations. Anthropological Science, vol. 106, pp. 199-208.

Kirch P.V., Swindler D.R., and Turner C.G. II (1989) Human skeletal and dental remains from Lapita sites (1600-500 BC) in the Mussau Islands, Melanesia. American Journal of Physical Anthropology, vol. 79, pp. 63-76.

Kitagawa Y., Manabe Y., Oyamada J., and Rokutanda A. (1995) Deciduous dental morphology of the prehistoric Jomon people of Japan: Comparison of nonmetric characters. American Journal of Physical Anthropology, vol. 97, pp. 101-112.

Kovacs I. (1971) A systematic description of dental roots. In Dahlberg A.A. ed., "Dental Morphology and Evolution”, The University of Chicago Press, Chicago, pp. 211-256.

Levy C.B. (1981) The dental morphology of pre-contact Micronesia: Mariana Islands. American Journal of Physical Anthropology, vol. 54, pp. 245.

Lum J.K. (1998) Central and eastern Micronesia: Genetics, the overnight voyage and linguistic divergence. Man and Culture in Oceania, vol. 14, pp. 69-80.

Matsuno M. (1997) Dental anthropological study on tooth size in Fiji, Western Samoa and 
Kiribati. Nihon University Journal of Oral Science, vol. 23, pp. 33-52 (In Japanese with English summary).

Mizoguchi Y. (1985) Shovelling: a statistical analysis of its morphology. University Museum, University of Tokyo, Bulletin, no. 26, pp. 1-176.

Pedersen P.O. (1949) The East Greenland Eskimo dentition. Meddelelser om Gronland, vol. 142, pp. 1-256.

Pietrusewsky M. (1990) Craniometric variation in Micronesia and the Pacific: A multivariate study. Micronesica (Suppl.), vol. 2, pp. 373-402.

Riesenfeld, A. (1956) Shovel-shaped incisors and a few other dental features among the native peoples of the Pacific. Anerican Journal of Physical Anthropology, vol. 14, pp. 505-522.

Riley T. (1987) Archaeological survey and testing, Majuro Atoll, Marshall Islands. In Dye T. ed., "Marshall Islands Archaeology", Pacific Anthropological Records, Honolulu, vol. 38 , pp. 169-270.

Shun K. and Athens J.S. (1990) Archaeological investigations on KwajeleinAtoll, Marshall Islands, Micronesia, Micronesica, vol. 2, pp. 231-240.

Smith P., Brown T., and Wood W.B. (1981) Tooth size and morphology in a recent Australian aboriginal population from Broadbeach, South East Australia, American Journal of Physical Anthropology, vol. 55, pp. 423-432.

Snow C.E. (1974) Early Hawaiians, An Initial Study of Skeletal Remains from Mokapu, Oahu. The University Press of Kentucky, Lexington.

Spennemann D.H.R. (1994) Excavations of a prehistoric cementery on Majuro Island, Majuro Atoll, Republic of the Marshall Islands. Johnstone Centre of Parks, Recreation, and Heritage, Report No. 13, Australia, Albury.

Streck C.S. (1990) Prehistoric settlement in eastern Micronesia: archaeology on Bikini Atoll Republic of the Marshall Islands. Micronesica, vol. 2, pp. 247-260.

Suzuki M., and Sakai T. (1964) Shovel-shaped incisors among living Polynesians. American Journal of Physical Anthropology, vol. 22, pp. 65-72.

Suzuki M., and Sakai T. (1973) Occlusal surface pattern of the lower molars and the deciduous molar among the living Polynesians. American Journal of Physical Anthropology, vol. 39, pp. 305-316.

Swindler D.R., Drusini A.G., and Cristino C. (1997) Variation and frequency of three-rooted first permanent molars in Precontact Easter Islanders: Anthropological significance. Journal of the Polynesian Society, vol.106, pp. 175-183.

Swindler D.R., Drusini A.G., Cristino C., and Ranzato C. (1998) Molar crown morphology of Precontact Easter Islanders compared with molars from other islands. In Stevens C.M., Lee G., and Norin F.J. eds., "Easter Island in Pacific Context South Seas Symposium”, Bearsville and Cloud Mountain Presses, Los Osos, pp. 163-168.

Swindler D.R., Drusini A.G., Cristino C., and Ranzato C. (1999) Comparison of molar crown size of Precontact Easter Islanders with other Pacific groups. In Mayhall J. and Heikkenen T. eds., "Dental Morphology, 1998”, University of Oulu Press, Oulu, pp. 63-73. 
Townsend G., Yamada H., and Smith P. (1990) Expression of the entoconulid (sixth cusp) on mandibular molar teeth of an Australian Aboriginal population. American Journal of Physical Anthropology, vol. 82, pp. 267-274.

Turner C.G. II (1970) New classification of non-metrical dental variation: cusps 6 and 7. American Journal of Physical Anthropology, vol. 33, pp. 144-145.

Turner C.G. II (1990a) Major feature of Sundadonty and Sinodonty, including suggestions about East Asian microevolution, population history, and late Pleistocene relationships with Australian aboriginals. American Journal of Physical Anthropology, vol. 82, pp. 295-318.

Turner C.G. II (1990b). Origin and affinity of the people of Guam: A dental anthropological assessment. Micronesica(Suppl), vol. 2, pp. 403-416.

Turner C.G. II and Scott G.R. (1977) Dentition of Easter Islanders. In Dahlberg A A. and Graber T.M. eds., "Orofacial Growth and Development", Mouton Publishers, Paris, pp. 229-249.

Turner C.G. II and Swindler D.R. (1978) The dentition of New Britain West Nakanai Melanesians. American Journal of Physical Anthropology, vol. 49, pp. 361-372.

Turner C.G. II, Nichol C.R., and Scott R.G. (1991) Scoring procedures for key morphological traits of the permanent dentition: the Arizona State University dental anthropology system. In Kelley M.A. and Larsen C.S. eds., “Advances in Dental Anthropology”, Wiley-Liss, Inc., New York, pp. 13-31.

Turner C.G. II and Hawkey D.E. (1998) Whose teeth are these? Carabelli's trait. In Lukas J.R. ed., "Human Dental Development, Morphology, and Pathology: A Tribute to Albert A. Dahlberg”, University of Oregon Anthropological Papers, Eugene, vol. 54 pp. 41-50.

Weisler M.I. (1999a) The antiquity of aroid pit agriculture and significance of buried A horizons on Pacific atolls. Geoarchaeology, vol. 14, pp. 621-654.

Weisler M.I. (1999b) Atolls as Settlement Landscapes: Ujae, Marshall Islands. Atoll Research Bulletin, Washington, D.C., pp. 1-51.

Weisler M.I., Lum J.K., Collins S.L., and Kimoto K. (2000) Status, health, and ancestry of a late prehistoric burial from Kwajalein Atoll, Marshall Islands. Micronesica, vol. 32, pp. 191-220.

Editor-in-Charge: Hajime Ishida 